\section{Antibiotic resistance in bacteria isolated from the skin of trout in León Province, Spain}

\author{
Juan-Miguel Fregeneda-Grandes ${ }^{1}$, Mohamed R. El Sayed ${ }^{1,2}$ \\ and Haitham H. Sayed ${ }^{* 3}$
}

${ }^{1}$ Departamento de Sanidad Animal, Facultad de Veterinaria, Universidad de León, León, España.

${ }^{2}$ Department of Fish diseases and Management, Faculty of Veterinary Medicine, Sohag University, Sohag, 82524, Egypt.

${ }^{3}$ Department of Microbiology, Faculty of Veterinary Medicine, Sohag University, Sohag, 82524, Egypt.
* Corresponding Author

Haitham H. Sayed, Department of Microbiology, Faculty of Veterinary Medicine, Sohag University, Sohag, 82524, Egypt.

E-mail: Haytham_adam@vet.sohag.edu.eg Submitted 10/2/2021

Accepted 10/23/2021

Published 11/5/2021

\begin{abstract}
Antibiotic resistance among fish pathogens has become a major concern. Integrons play an important role in dissemination of antibiotics resistance genes among the different species of bacteria. This study was designed to determine the antibiotic susceptibility of 20 bacterial isolates were isolated from the skin of brown trout (Salmo trutta) and rainbow trout (Oncorhynchus mykiss) collected from the rivers and fish farms in León Province, Spain and to detect class 1 and 2 integrons in these isolates by PCR to explore the role of these integrons in the antibiotic resistance. The investigated isolates included Pseudomonas fluorescens (P. fluorescens) $(\mathrm{n}=5)$, Aeromonas sobria (A. sobria) $(\mathrm{n}=3)$, Pantoea agglomerans ( $P$. agglomerans) $(\mathrm{n}=3)$, Acinetobacter johnsonii (A. johnsonii) $(\mathrm{n}=2)$, Serratia fonticola (S. fonticola) $(\mathrm{n}=1)$, Staphylococcus equorum (S. equorum) $(\mathrm{n}=3)$, Yersinia kristensenii (Y. kristensenii) $(\mathrm{n}=2)$ and Xanthomonas retroflexus (X. retroflexus) $(\mathrm{n}=1)$. Antimicrobial susceptibility testing for the isolates revealed that they were sensitive to enrofloxacin (100\%) and gentamicin (95\%) while resistant to ampicillin (90\%) and tetracycline $(80 \%)$. PCR revealed that all the isolates didn't harbor class 1 or 2 integrons. Therefore, the indiscriminate use of antibiotics must be restricted and more attention should be paid to biosecurity measures in aquaculture. Also, further studies are needed to assess role of integrons and other genetic elements in antimicrobial resistance in aquaculture.
\end{abstract}

Keywords: Antimicrobial, Integrons, León Province, Resistance, Trout

\section{Introduction}

The emergence of antimicrobial resistance among fish pathogens during the past decades, became a major concern in many countries (Schmidt et al., 2001) where it undermines effectiveness of antibiotics in aquaculture and increases the possibilities for passage of these antibiotic-resistant bacteria and their antibiotic resistance determinants to bacteria of terrestrial animals and human, including pathogens (Cabello, 2006). This in addition to that development of new antibiotics by the pharmaceutical industry had essentially stalled due to economic and regulatory obstacles (Bartlett et al., 2013).Antibiotic resistance in bacterial populations can result from the clonal selection under antimicrobial selective pressure or through horizontal genes transfer (Deng et al., 2016). The growth of aquaculture worldwide has been accompanied by a rapid increase in the therapeutic and prophylactic use of antimicrobials including those important in human therapeutics (Cabello et al., 2013). The use of a wide variety of antimicrobials in large amounts ensures their remaining in the aquatic environments for prolonged time periods exerting their selective pressure which has led to emergence of antibiotic-resistant bacteria in aquaculture environments, increase of antibiotic resistance of fish pathogens, and to alteration of bacterial flora in aquaculture environments (Cabello, 2006 and Cabello et al., 2013). Mobile genetic elements as plasmids, transposons, and integrons play a big role in evolution and dissemination of antimicrobial resistance in the aquatic environment through their wide dissemination for antimicrobial resistance genes between bacteria by horizontal gene transfer (Khan et al., 2009). Integrons are specialized genetic elements capable of capturing, 
integrating, and mobilizing gene cassettes. They are widely present among bacteria (Xu et al., 2009) and their occurrence in fish-farming environments is well known (Ndi and Barton, 2011). Integrons could be horizontally transferred among bacteria of inter- and intra-species (Lukkana et al., 2012) and they are often situated on conjugative plasmids or transposons which can facilitate and accelerate their lateral transfer between bacteria (Mazel, 2006).Although plasmids are the most important agents for appearance and dissemination of antibiotic resistance (Smith and Romesberg, 2007), integrons constitute an important means of spreading antibiotic resistance genes (Partridge et al., 2009). More than 100 different gene cassettes have been found within integrons, most of them encode for antibiotic resistance (Sarria-Guzmán et al., 2014). Integrons can capture more than one antibiotic-resistant cassette (Sarria-Guzmán et al., 2014) and numerous combinations of gene cassettes have been reported within integrons (Partridge et al., 2009) which may lead to multi-resistance (Fluit and Schmitz, 1999). There are three classes of integrons involved in antimicrobial resistance but class 3 integrons rarely emerges in clinical isolates $(\mathrm{Xu}$ et al., 2009).Several recently found genetic elements and resistance determinants for quinolones, tetracyclines, and $\beta$-lactamases are shared between aquatic bacteria, fish pathogens, and human pathogens, and appear to have originated in aquatic bacteria (Cabello et al., 2013). Limited data are available about antimicrobial resistance in skin microbiota of trout and role of integrons in this resistance. Therefore, this study was aimed to determine the antimicrobial susceptibility of bacteria isolated from skin of brown and rainbow trout collected from the rivers and fish farms in León Province, Spain and to detect class 1 and 2 integrons in these isolates by PCR to explore role of these integrons in the antimicrobial resistance.

\section{Materials and Methods}

\section{Bacterial isolates:}

This study was performed on 20 different bacterial isolates were isolated and identified by CarbajalGonzález et al. (2011) from skin of brown $(n=18)$ and rainbow $(n=2)$ trout collected from the rivers $(n=13)$ and fish farms $(n=7)$ in León Province, Spain, these isolates and origin of their isolation were illustrated in Table (1). These bacterial isolates were stored at $-80^{\circ} \mathrm{C}$ in tryptone soya broth (TSB) supplemented with $15 \%$ glycerol.
Table 1. The investigated bacterial isolates in this study and origin of their isolation.

\begin{tabular}{|c|c|c|c|c|}
\hline \multirow{2}{*}{ Strain code } & \multicolumn{2}{|c|}{ Bacteria } & \multicolumn{2}{|c|}{ Origin of isolation } \\
\hline & Species & Number & Fish species & Source of fish \\
\hline LE89 & \multirow{5}{*}{ P. fluorescens } & \multirow{5}{*}{5} & brown trout & Porma River \\
\hline LE98 & & & brown trout & Porma River \\
\hline LE122 & & & brown trout & fish farm on Porma River \\
\hline LE141 & & & rainbow trout & fish farm on Duerna River \\
\hline LE143 & & & rainbow trout & fish farm on Duerna River \\
\hline LE51 & \multirow{3}{*}{ A. sabra } & \multirow{3}{*}{3} & brown trout & Omaña River \\
\hline LE74 & & & brown trout & fish farm on Porma River \\
\hline LE80 & & & brown trout & fish farm on Porma River \\
\hline LE35 & \multirow{3}{*}{ P. agglomerans } & \multirow{3}{*}{3} & brown trout & Porma River \\
\hline LE36 & & & brown trout & Porma River \\
\hline LE37 & & & brown trout & Porma River \\
\hline LE4 & \multirow{2}{*}{ A. johnsonii } & \multirow{2}{*}{2} & brown trout & Porma River \\
\hline LE7 & & & brown trout & Porma River \\
\hline LE52 & S. fonticola & 1 & brown trout & Omaña River \\
\hline LE6 & \multirow{3}{*}{ S. equortum } & \multirow{3}{*}{3} & brown trout & Porma River \\
\hline LE11 & & & brown trout & fish farm on Porma River \\
\hline LE13 & & & brown trout & fish farm on Porma River \\
\hline LE54 & \multirow{2}{*}{ Y. kristensenii } & \multirow{2}{*}{2} & brown trout & Omaña River \\
\hline LE58 & & & brown trout & Omaña River \\
\hline LE38 & X. retroflexus & 1 & brown trout & Porma River \\
\hline
\end{tabular}

In this study, the bacterial isolates were defrosted and cultured on TSA (Cultimed, Belgium) and incubated aerobically at $22^{\circ} \mathrm{C}$ for 24 hours. Subsequently, the isolates identification was confirmed through their morphological characters, Gram staining, oxidase test and catalase test. Furthermore, any doubtful isolate was identified by MALDI-TOF MS (Bizzini and Greub, 2010) and the results were interpreted following the manufacturer's recommendation.

\section{Antibiotic susceptibility testing of the isolates:}

Antibiotic susceptibility of the isolates was determined by using Kirby-Bauer disk diffusion method against four different antibiotics including ampicillin $(10 \mu \mathrm{g})$, gentamicin $(10 \mu \mathrm{g})$, enrofloxacin $(10 \mu \mathrm{g})$ and tetracycline $(30 \mu \mathrm{g})$ (Oxoid, Spain). Bacterial suspensions of the isolates were prepared and adjusted to $1.5 \times 108 \mathrm{CFU} / \mathrm{mL}$ by using Sensititre ${ }^{\mathrm{TM}}$ Nephelometer (Thermo Scientific, USA). Subsequently, an aliquot of each suspension was spread plated onto Mueller-Hinton agar (Oxoid, Spain) then antibiotic disks were dispensed on the inoculated plate and incubated aerobically at $22^{\circ} \mathrm{C}$ for 18-24 hours. Inhibition zones diameters were measured and interpreted according to CLSI (2014).

\section{Molecular detection of class 1 and 2 integron- integrase genes (intI1 and intI2) in the isolates:}

\subsection{DNA extraction:}

Bacterial isolates were cultured on TSA then bacterial colonies were harvested and placed into sterile Eppendorf tubes containing $100 \mu \mathrm{l}$ of phosphate buffered saline ( $\mathrm{pH}$ 7.4). Subsequently, the suspensions were heated in water bath at $100^{\circ} \mathrm{C}$ for 10 
min. then centrifuged at $14000 \mathrm{rpm}$ for $5 \mathrm{~min}$. (Holmes and Quigley, 1981). The supernatants were transferred into fresh Eppendorf tubes and used as DNA templates for PCR.

\subsection{DNA amplification:}

Isolates were screened for presence of class 1 and 2 integrons through amplification of bacterial DNA targeting class 1 and 2 integron-integrase genes (intI1 and intI2) using the oligonucleotide primers illustrated in Table (2) (Shibata et al., 2003). PCR mixture was prepared in $25 \mu \mathrm{l}$ volumes containing $2.5 \mu \mathrm{l}$ of 100 $\mathrm{mM}$ PCR buffer (Biotools), $1.25 \mu \mathrm{l}$ of $50 \mathrm{mM} \mathrm{MgCl} 2$ (Invitrogen $^{\mathrm{TM}}$ ), $0.8 \mu \mathrm{l}$ of $4 \mathrm{mM}$ deoxynucleotide triphosphate mix, $0.5 \mu \mathrm{l}$ of each primer, $2 \mu \mathrm{l}$ of the extracted DNA, $0.15 \mu \mathrm{l}$ of $5 \mathrm{U} / \mu \mathrm{l}$ DNA Polymerase (Biotools) and $17.3 \mu \mathrm{l}$ of sterile milliQ water. PCR was performed in SimpliAmp ${ }^{\mathrm{TM}}$ thermal cycler (Thermo Scientific, USA) under the conditions previously described by Dillon et al. (2005); initial denaturation at $95^{\circ} \mathrm{C}$ for $5 \mathrm{~min}$. followed by 30 cycles of denaturation at $95^{\circ} \mathrm{C}$ for $30 \mathrm{sec}$., annealing at $55^{\circ} \mathrm{C}$ for $30 \mathrm{sec}$. and extension at $72^{\circ} \mathrm{C}$ for $90 \mathrm{sec}$. followed by final extension step at $72^{\circ} \mathrm{C}$ for $7 \mathrm{~min}$.

\subsection{Analysis of PCR products:}

PCR products were electrophoresed on $1 \%$ agarose gel in $1 \mathrm{x}$ Tris-acetate EDTA buffer at $90 \mathrm{~V}$ and $400 \mathrm{~mA}$ for $40 \mathrm{~min}$. and $100 \mathrm{bp}$ DNA ladder was used for fragments size determination. Thereafter, the gel was photographed by a gel documentation system (Biorad, USA) and data was analyzed.

Table 2. Target genes and oligonucleotide primers used in this study.

\begin{tabular}{|c|c|c|c|}
\hline $\begin{array}{c}\text { Target } \\
\text { gene }\end{array}$ & \multicolumn{2}{|r|}{ Primers sequences $\left(5^{\prime}-3^{\prime}\right)$} & $\begin{array}{l}\text { Product size } \\
\text { (bp) }\end{array}$ \\
\hline \multirow{2}{*}{ Int $\mathrm{I} 1$} & $\mathrm{~F}$ & GCATCCTCGGTTTTCTGG & \multirow{2}{*}{457} \\
\hline & $\mathrm{R}$ & GGTGTGGCGGGCTTCGTG & \\
\hline \multirow{2}{*}{ Int $\mathrm{I} 2$} & $\mathrm{~F}$ & CACGGATATGCGACAAAAAGGT & \multirow{2}{*}{789} \\
\hline & $\mathrm{R}$ & GTAGCAAACGAGTGACGAAATG & \\
\hline
\end{tabular}

\section{Statistical analysis:}

The statistical analysis was performed by using Epi Info $^{\mathrm{TM}}$ software (version 7.2.4). The differences in antimicrobial resistance between bacteria isolated from rivers trout and those isolated from farms trout were estimated by Chi-Square and Fisher's exact tests, with an $\alpha=0.05$ cutoff.

\section{Results}

\section{Antibiotic susceptibility of the isolates:}

Results of antimicrobial susceptibility testing of the bacterial isolates to the tested antibiotics were illustrated in Tables (3) and (4). Statistical analysis revealed that there was no significant difference between the antimicrobial resistance of bacteria isolated from rivers trout and those isolated from farms trout.

Table 3. Results of antibiotic susceptibility of bacterial isolates.

\begin{tabular}{|c|c|c|c|c|c|c|c|c|c|c|c|}
\hline 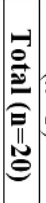 & 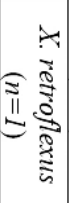 & 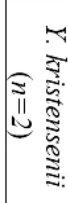 & 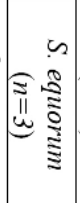 & 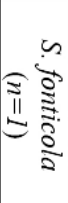 & 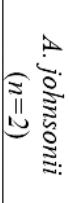 & 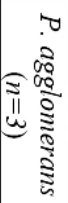 & 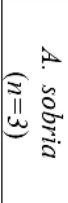 & 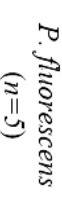 & \multicolumn{3}{|c|}{$\frac{\vec{g}}{\hat{\vec{b}}}$} \\
\hline$N$ & 0 & 0 & $N$ & 0 & 0 & 0 & 0 & 0 & ZZ & $\begin{array}{l}\mathscr{2} \\
\mathbb{2}\end{array}$ & \\
\hline \% & 0 & 0 & $\stackrel{2}{2}$ & 0 & 0 & 0 & 0 & 0 & $0^{\circ}$ & & \\
\hline $\mid \infty$ & - & $N$ & 耐 & - & $N$ & $\omega$ & $\omega$ & ur & 겨 & 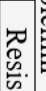 & \\
\hline ঃ & ঃ & ঃ & $\underset{\omega}{\omega}$ & $\overline{8}$ & $\overline{8}$ & 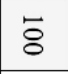 & ঃ & $\overline{8}$ & $0^{\circ}$ & $\overrightarrow{\underline{\vec{\Xi}}}$ & \\
\hline $\overrightarrow{0}$ & 0 & $N$ & $\omega$ & - & $N$ & $\omega$ & $\omega$ & ur & ż & 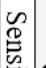 & \\
\hline 它 & 0 & $\overline{8}$ & ‡ & ¿ & $\overline{8}$ & ¿ & $\overline{8}$ & $\overline{8}$ & $\therefore$ & 尝: & \\
\hline-1 & - & 0 & 0 & 0 & 0 & 0 & 0 & 0 & Zz & 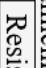 & \\
\hline ur & $\overline{8}$ & 0 & 0 & 0 & 0 & 0 & 0 & 0 & $0^{\circ}$ & 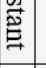 & \\
\hline$\stackrel{1}{\circ}$ & - & $N$ & $\omega$ & - & $N$ & $\omega$ & $\omega$ & ur & za & $\begin{array}{l}\tilde{D} \\
\mathbb{D} \\
\tilde{U}\end{array}$ & \\
\hline 요 & ऽ & $\overline{8}$ & ๖ & 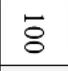 & $\overline{8}$ & 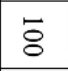 & 요 & $\stackrel{\circ}{\circ}$ & $0^{\circ}$ & 尝: & \\
\hline 0 & 0 & 0 & 0 & 0 & 0 & 0 & 0 & 0 & ZZ & & 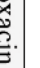 \\
\hline 0 & 0 & 0 & 0 & 0 & 0 & 0 & 0 & 0 & $0^{\circ}$ & $\overrightarrow{\overrightarrow{\mathrm{E}}}$ & \\
\hline 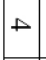 & 0 & 0 & $N$ & 0 & 0 & 0 & $N$ & 0 & Zz & $\mathscr{\bigotimes}$ & \\
\hline 今 & 0 & 0 & $\stackrel{\text { g }}{ }$ & 0 & 0 & 0 & $\stackrel{a}{a}$ & 0 & $0^{\circ}$ & 产: & \\
\hline$\vec{a} \mid$ & - & $N$ & 蒠 & - & $N$ & $\omega$ & 笖 & ur & 고 & 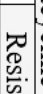 & ह. \\
\hline$\stackrel{\infty}{\circ}$ & $\bar{ঃ}$ & $\overline{8}$ & $\underset{\omega}{\omega}$ & ঃ & ঃ & 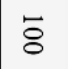 & $\underset{\omega}{\omega}$ & $\overline{8}$ & $0^{\circ}$ & 总 & \\
\hline
\end{tabular}

Table 4. Results of antibiotic susceptibility of bacterial isolates isolated from rivers trout and farms trout.

\begin{tabular}{|c|c|c|c|c|c|c|c|c|c|c|c|c|c|c|c|c|}
\hline \multirow{4}{*}{ Isolates } & \multicolumn{16}{|c|}{ Antimicrobial susceptibility result } \\
\hline & \multicolumn{4}{|c|}{ Ampicillin } & \multicolumn{4}{|c|}{ Gentamicin } & \multicolumn{4}{|c|}{ Enrofloxacin } & \multicolumn{4}{|c|}{ Tetracycline } \\
\hline & \multicolumn{2}{|c|}{ Sensitive } & \multicolumn{2}{|c|}{ Resistant } & \multicolumn{2}{|c|}{ Sensitive } & \multicolumn{2}{|c|}{ Resistant } & \multicolumn{2}{|c|}{ Sensitive } & \multicolumn{2}{|c|}{ Resistant } & \multicolumn{2}{|c|}{ Sensitive } & \multicolumn{2}{|c|}{ Resistant } \\
\hline & $\mathrm{N}_{0 .}$ & $\%$ & $\mathrm{~N}_{0 .}$ & $\%$ & No. & $\%$ & No. & $\%$ & $\mathrm{~N}_{0}$ & $\%$ & No. & $\%$ & $\mathrm{~N}_{0}$ & $\%$ & No. & $\%$ \\
\hline $\begin{array}{c}\text { Rivers trout } \\
(\mathrm{n}=13)\end{array}$ & 1 & 7.7 & 12 & 92.3 & 12 & 92.3 & 1 & 7.7 & 13 & 100 & 0 & 0 & 1 & 7.7 & 12 & 92.3 \\
\hline $\begin{array}{c}\text { Farms trout } \\
(\mathrm{n}=7)\end{array}$ & 1 & 14.3 & 6 & 85.7 & 7 & 100 & 0 & 0 & 7 & 100 & 0 & 0 & 3 & 42.9 & 4 & 57.1 \\
\hline $\begin{array}{l}\text { Total } \\
(\mathrm{n}=20)\end{array}$ & 2 & 10 & 18 & 90 & 19 & 95 & 1 & 5 & 20 & 100 & 0 & 0 & 4 & 20 & 16 & 80 \\
\hline
\end{tabular}




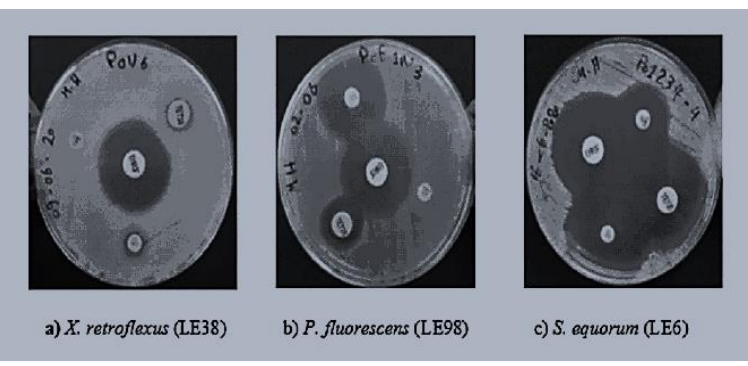

Fig. 1. Antibiotic susceptibility test results of some bacterial isolates.

\section{Molecular detection of class 1 and 2 integron-} integrase genes (intI1 and intI2):

It was found that all the examined isolates didn't harbor IntI1 or IntI2 genes as illustrated in Fig. (2).

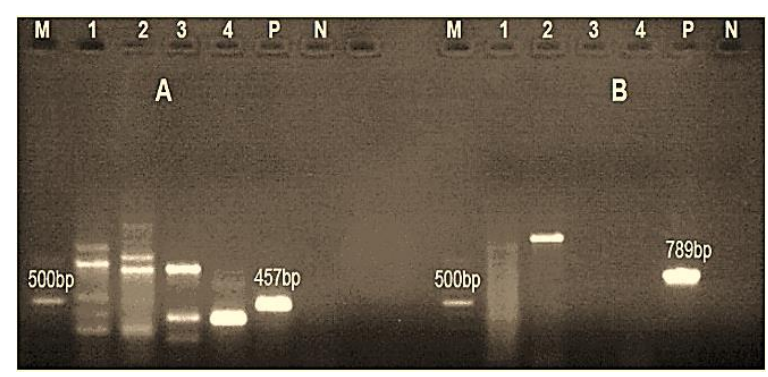

Fig. 2. Agar gel electrophoresis for PCR products using specific primers target IntI1 (Part A) and IntI2 (Part B) genes in the isolates. Lane M: $100 \mathrm{bp}$ molecular weight marker, lane P: positive control, lane $\mathrm{N}$ : negative control and lanes 1-4: DNA extracted from LE89, LE141, LE51 and LE80 isolates respectively showing negative results for both genes in all of them.

\section{Discussion}

Antimicrobial resistance is an issue of increasing global concern and it is associated mainly with the uncontrolled use of antimicrobials (Barber et al., 2003). There are numerous reports about resistance of fish pathogens to one or several antibiotics (Schmidt et al., 2001). In this study, it was found that (100\%) and $(95 \%)$ of the examined bacterial isolates were sensitive to enrofloxacin and gentamicin respectively while $(90 \%)$ and $(80 \%)$ of them were resistant to ampicillin and tetracycline respectively and there was no significant difference between the antibiotic resistance of bacteria isolated from the rivers trout and those isolated from farms trout. These results may be attributed to the prolonged and misuse of ampicillin and tetracycline and presence of regulation framework for use of enrofloxacin and gentamicin in the fish farms and the areas around the rivers from which the samples were collected or may be due to the intrinsic resistome of some bacterial species to ampicillin and tetracycline as the intrinsic resistome of A. sobria to penicillins (Borella et al., 2020 and Dhanapala et al., 2021). Resistance of these different bacterial isolates to ampicillin and tetracycline will result in difficulty of prevention and control of the bacterial diseases of fish, in addition to their epidemiological and public health implications represented in transfer of these resistant bacteria and their resistance genes to human and animals, especially that penicillins and tetracyclines are among the six critically important antimicrobials for human medicine (WHO, 2017). Therefore, antibiotics use in aquaculture and other livestock production sectors must be prudent and supported by antimicrobial susceptibility testing in addition to application of strict hygienic measures in aquaculture.

Our results agreed with findings of Dinçtürk and Tanrıkul (2021) except in the sensitivity to tetracycline where they found that all $P$. fluorescens isolated from rainbow trout were resistant to ampicillin and sensitive to enrofloxacin and tetracycline. Also, our results agreed with findings of Kozińska et al. (2014) and Borella et al. (2020) who found that all A. johnsonii and A. sobria isolates respectively were resistant to ampicillin and sensitive to gentamicin. While in contrast to our results, Elabd et al. (2020) and Dhanapala et al. (2021) found that all A. johnsonii and A. sobria isolates were resistant gentamycin and enrofloxacin respectively. These differences in the antimicrobial susceptibility may be attributed to some differences including the used antimicrobials, management practices, and time of examination where antimicrobial resistance is increasing over time (Ali et al., 2017).

Integrons constitute an important means for spreading antibiotic resistance (Partridge et al., 2009). Three classes of integrons are involved in the bacterial resistance but class 3 integron rarely emerges in the clinical isolates (Xu et al., 2009). Isolates originating from aquatic sources have been reported to carry integrons and other genes that code for resistance (Ndi and Barton, 2011). In this study, it was found that all the investigated isolates didn't harbor class 1 or 2 integrons as illustrated in Fig. (2). Our results agreed with findings of Ranjbar et al. (2019) who didn't detect class 2 integrons in all investigated Aeromonas species isolated from the diseased freshwater animals and water samples in Iran while disagreed with findings of Dhanapala et al. (2021) who detected class 1 and 2 
integrons in (19.9\%) of Aeromonas species isolated from freshwater ornamental fish and associated farming environment in Sri Lanka. Class 1 integrons were also detected in A. sobria by Ndi and Barton (2011), Sarria-Guzmán et al. (2014) and Deng et al. (2016).

The genetically determined resistance set up by given bacteria is efficiently transmitted to its clonal expansion and/or other bacteria through the mobile genetic elements as plasmids, transposons, and integrons (Sultan et al., 2018). In this study, it was found that the investigated bacterial isolates were resistant to ampicillin and tetracycline although they didn't harbor class 1 or 2 integrons, resistance of these isolates may be attributed to that genes which conferred such resistance were situated on the other mobile genetic elements as plasmids and transposons which aren't investigated in our study or may be attributed to the intrinsic resistome which is documented in Aeromonas spp. to penicillins (Borella et al., 2020 and Dhanapala et al., 2021). Furthermore, this may be also attributed to the few bacterial isolates number investigated in this study, therefore, further studies are required to explore role of integrons and other genetic elements in the antimicrobial resistance.

\section{Conclusion}

The current study revealed that bacteria isolated from skin of brown and rainbow trout collected from the rivers and farms in León Province, Spain were resistant to ampicillin and tetracycline while sensitive to enrofloxacin and gentamicin and didn't harbor class 1 or 2 integrons, representing risk for both human and fishes. Therefore, the indiscriminate use of antibiotics must be restricted and more attention should be paid to biosecurity measures in aquaculture. Furthermore, further studies are required to assess role of integrons and other genetic elements in antimicrobial resistance in aquaculture.

\section{Conflict of interest}

The authors declare that they have no competing interest.

\section{References}

Ali Y, Islam MA, Muzahid NH, Faruk SM, Hossain MA and Marzan LW (2017). Characterization, prevalence and antibiogram study of Staphylococcus aureus in poultry. Asian Pacific Journal of Tropical Biomedicine, 7(3): 253-256.

Barber DA, Miller GY and McNamara PE (2003). Models of antimicrobial resistance and foodborne illness: Examining assumptions and practical applications. Journal of Food Protection, 66:700-709.

Bartlett JG, Gilbert DN and Spellberg B (2013). Seven ways to preserve

the miracle of antibiotics. Clinical Infectious Diseases, 56 (10):1445-1450.

Bizzini A and Greub G (2010). Matrix-assisted laser desorption ionization time-of-light mass spectrometry, a revolution in clinical microbial identification. Clinical Microbiology and Infection, 16(11):16141619.

Borella L, Salogni C, Vitale N, Scali F, Moretti VM, Pasquali P and Alborali GL (2020). Motile aeromonads from farmed and wild freshwater fish in northern Italy: An evaluation of antimicrobial activity and multidrug resistance during 2013 and 2016. Acta Veterinaria Scandinavica, 62:6.

Cabello FC (2006). Heavy use of prophylactic antibiotics in aquaculture: A growing problem for human and animal health and for the environment. Environmental Microbiology, 8(7):1137-1144.

Cabello FC, Godfrey HP, Tomova A, Ivanova L, Dölz H, Millanao A and Buschmann AH (2013). Antimicrobial use in aquaculture re-examined: Its relevance to antimicrobial resistance and to animal and human health. Environmental Microbiology, 15 (7):1917-1942.

Carbajal-González MT, Fregeneda-Grandes JM, Suárez-Ramos S, Cadenas FR and Aller-Gancedo JM (2011). Bacterial skin flora variation and in vitro inhibitory activity against Saprolegnia parasitica in brown and rainbow trout. Diseases of Aquatic Organisms, 96(2): 125-135.

CLSI (2014). Performance Standards for Antimicrobial Susceptibility Testing of Bacteria Isolated from Aquatic Animals; Second Informational Supplement. VET03/VET04-S2, Clinical and Laboratory Standards Institute, Wayne, PA, USA.

Deng Y, Wu Y, Jiang L, Tan A, Zhanng R and Luo L (2016). Multi-drug resistance mediated by class 1 Integrons in Aeromonas isolated from farmed freshwater animals. Frontiers in microbiology, 7:935.

Dillon B, Thomas L, Mohmand G, Zelynski A and Iredell J (2005). Multiplex PCR for screening of 
integrons in bacterial lysates. Journal of Microbiological Methods, 62(2): 221-232.

Dinçtürk E and Tanrikul TT (2021). Yersinia ruckeri and Pseudomonas fluorescens co-infection in rainbow trout (Oncorhynchus mykiss Walbaum, 1792). Aquaculture Research, 52:4858-4866.

Dhanapala PM, Kalupahana RS, Kalupahana AW, Wijesekera DPH, Kottawatta SA, Jayasekera NK, Silva-Fletcher A and De S Jagoda, SSS (2021). Characterization and antimicrobial resistance of environmental and clinical Aeromonas species isolated from freshwater ornamental fish and associated farming environment in Sri Lanka. Microorganisms, 9: 2106.

Elabd H, Abd El-latif AM, Shaheen A and Matter A (2020). Identification of emerging Acinetobacter johnsonii virulence and antibiotic resistance genes associated with high mortality in cultured Oreochromis niloticus. Egyptian Journal for Aquaculture, 10 (2):19-33.

Fluit A and Schmitz FJ (1999). Class 1 integrons, gene cassettes, mobility, and epidemiology. European Journal of Clinical Microbiology and Infectious Diseases, 18: 761-770.

Holmes DS and Quigley M (1981). A rapid boiling method for the preparation of bacterial plasmids. Analytical biochemistry, 114(1): 193-197.

Khan AA, Ponce E, Nawaz MS, Cheng C-M, Khan JA and West CS (2009). Identification and characterization of class 1 integron resistance gene casetes among Salmonella strains isolated from imported seafood. Applied and Environmental Microbiology Journal, 75 (4): 1192-1196.

Kozińska A, Paździor E, Pękala A and Niemczuk W (2014). Acinetobacter johnsonii and Acinetobacter lwoffii - the emerging fish pathogens. Bulletin of the Veterinary Institute in Pulawy, 58: 193-199.

Lukkana M, Wongtavatchai $\mathrm{J}$ and Chuanchuen $\mathrm{R}$ (2012). Class 1 integrons in Aeromonas hydrophila isolates from farmed Nile tilapia (Oreochromis nilotica). Journal of Veterinary Medical Science, 74 (4): 435-440.

Mazel D (2006). Integrons: agents of bacterial evolution. Nature Reviews Microbiology, 4: 608-620.

Ndi OL and Barton MD (2011). Incidence of class 1 integron and other antibiotic resistance determinants in Aeromonas spp. from rainbow trout farms in Australia. Journal of Fish Diseases, 34: 589-599.
Partridge SR, Tsafnat G, Coiera E and Iredell JR (2009). Gene cassettes and cassette arrays in mobile resistance integrons. FEMS Microbiology reviews, 33: 757-784.

Ranjbar R, Salighehzadeh R and Sharifiyazdi H (2019). Antimicrobial resistance and incidence of integrons in Aeromonas species isolated from diseased freshwater animals and water samples in Iran. Antibiotics, 8, 198.

Sarria-Guzmán Y, López-Ramírez MP, ChávezRomero Y, Ruiz-Romero E, Dendooven L and BelloLópez JM (2014). Identification of antibiotic resistance cassettes in class 1 integrons in Aeromonas spp. strains isolated from fresh fish (Cyprinus Carpio L.). Current Microbiology, 68 (5): 581-586.

Schmidt AS, Bruuna MS, Larsena JL and Dalsgaard I (2001). Characterization of class 1 integrons associated with R-plasmids in clinical Aeromonas salmonicida isolates from various geographical areas. Journal of Antimicrobial Chemotherapy, 47: 735-743.

Shibata N, Doi Y, Yamane K, Yagi T, Kurokawa H, Shibayama K, Kato H, Kai K and Arakawa Y (2003). PCR typing of genetic determinants for metallo- $\beta$ lactamases and integrases carried by gram-negative bacteria isolated in Japan, with focus on the class 3 integron. Journal of Clinical Microbiology, 41(12):5407-5413.

Smith PA and Romesberg FE (2007). Combating bacteria and drug resistance by inhibiting mechanisms of persistence and adaptation. Nature chemical biology, 3(9): 549-556.

Sultan I, Rahman S, Jan, AT, Siddiqui MT, Mondal AH and Haq QMR (2018). Antibiotics, resistome and resistance mechanisms: A bacterial perspective. Frontiers in microbiology, 9, 2066.

WHO (2017). Critically important antimicrobials for human medicine: Ranking of antimicrobial agents for risk management of antimicrobial resistance due to non-human use.

Xu H, Su Z, Wang S, Dai X, Chen J, Kong F, Li Y, Peng S, Shao Q and Lu L (2009). Four novel resistance integron gene-cassette occurrences in bacterial isolates from Zhenjiang, China. Current Microbiology, 59 (2): 113-117. 